\title{
CONGENITAL DISLOCATION OF THE HIP IN BUDAPEST, HUNGARY
}

\author{
A. CZEIZEL, T. VIZKELETY, AND J. SZENTPÉTERI \\ National Institute of Public Health, Budapest, and Department of Orthopaedics, Semmelweis University of \\ Medical Sciences, Budapest, Hungary
}

For the last few years nearly all newborn infants born in Budapest, a city of two million inhabitants, have received an orthopaedic examination which includes a screening test for congenital dislocation of the hip $(\mathrm{CDH})$. Suspected cases of $\mathrm{CDH}$ were kept under observation and received treatment if necessary. In this way a total of 3,000 treated cases born between 1962 and 1967 became available for study.

\section{Material and Methods}

1. An attempt was made to estimate the incidence of $\mathrm{CDH}$ among the 108,966 infants born alive in Budapest between 1962 and 1967. During this period $99.6 \%$ of all births took place in hospital. Almost all would have been screened for $\mathrm{CDH}$ either in the hospital where they were born, or under the national health insurance district paediatrics scheme, or through paediatric-orthopaedic consultations. Index patients could thus be collected from the registry of the Department of Orthopaedics, Semmelweis University, and from the records of the 27 paediatric-orthopaedic and orthopaedic district consultations in Budapest. Only patients who had received orthopaedic treatment were included in these studies. (Patients who were maintained in abduction only were excluded since the presence of $\mathrm{CDH}$ in these cases could not be proved.) The necropsy records of pathology departments in Budapest and the Hungarian Congenital Malformations Register were also consulted. The diagnosis (luxation, subluxation, dysplasia), the site of the dislocation, the treatment applied, and the personal data available were recorded on personal cards for each of the index patients. The personal cards were addressed by name and this helped to avoid multiple entry of the same case.

The principles of $\mathrm{CDH}$ diagnosis in Hungary are the following: isolated asymmetry of the gluteal folds or restricted abduction alone do not establish the diagnosis. Asymmetry of the hips and the folds, laxity, and a tendency to dislocation of the hip joint on manipulation, and restricted abduction with an abduction contracture on the other side all make the diagnosis of $\mathrm{CDH}$ probable. The occurrence of the Ortolani click and/or the Barlow-LeDamany sign confirms the diagnosis. It is the relation of the acetabulum to the femoral neck metaphysis and the acetabular angle, determined on radiographs taken after the fourth month, that finally makes the diagnosis unequivocal. In doubtful cases, only maintenance of abduction by swaddling and longterm follow-up are required. In our view, five conditions have to be distinguished in connexion with the diagnosis of $\mathrm{CDH}$ : (1) Laxity of the joint. This is frequently observed at birth and sometimes leads to the diagnosis in the newborn of pseudodislocation. (2) 'Dysplasia' of the hip joint, once thought to be a precursor of $\mathrm{CDH}$ which might recover without treatment but is now believed to be a secondary condition. (3) Congenital dislocation of the hip which, though detectable immediately after birth in a few cases, usually develops postnatally. (4) Teratological dislocation. This can be detected at birth and is a component of a multiple malformation syndrome (e.g., arthrogryposis). (5) Secondary dislocation which develops after birth as a secondary consequence of other more severe conditions (e.g., spina bifida or spastic cerebral paralysis). Types 2 and 3 may represent the same nosological entity. Their separation from type 1 has been attempted in our survey, only those cases which had been treated being considered. However, the reliability of this separation is doubtful. Separation of types 2 and 3 from the rare types 4 and 5 was not difficult; in our material 17 such cases (1\%) occurred.

2. A questionnaire with a covering letter and a self-addressed prepaid envelope was sent to the mother of each index patient. Of the 3,000 questionnaires dispatched, 1,298 were returned; $482(16.1 \%)$ could not be delivered because the address was wrong. Another questionnaire with a new version of covering letter was sent to each of the 1,220 families who had not returned the first one. Of these, 762 were returned. Of the total of 2,060 questionnaires returned, 293 were incomplete and had 
TABLE I

INCIDENCE OF CONGENITAL DISLOCATION OF THE HIP (LUXATION, SUBLUXATION, DYSPLASIA) IN BUDAPEST, 1962-67

\begin{tabular}{|c|c|c|c|c|c|c|c|c|}
\hline Type & No. ${ }^{1962} \%$ & No. ${ }^{1963} \%$ & No. ${ }^{1964} \%$ & No. ${ }^{1965} \%$ & No. ${ }^{1966} \%$ & $\begin{array}{l}19 \\
\text { No. }\end{array}$ & $67 \%$ & $\begin{array}{c}1962-67 \\
\text { No. } \%\end{array}$ \\
\hline $\begin{array}{l}\text { Luxation and subluxation } \\
\text { Dysplasia }\end{array}$ & $\begin{array}{l}37 \cdot 4 \\
42 \cdot 1) \\
62 \cdot 6 \\
53 \cdot 1) \\
\end{array}$ & $\begin{array}{l}28 \cdot 7 \\
42 \cdot 5) \\
71 \cdot 3 \\
53 \cdot 0)\end{array}$ & $\begin{array}{r}142 \\
(71 \\
334 \\
(208 \\
\end{array}$ & $\begin{array}{|cc|}143 & 26 \cdot 7 \\
(77 & 53 \cdot 8) \\
392 & 73 \cdot 3 \\
(244 & 62 \cdot 2) \\
\end{array}$ & $\begin{array}{rl}185 & 29 \cdot 4 \\
(114 & 61.6) \\
445 & 70 \cdot 6 \\
(280 & 62.9)\end{array}$ & $\begin{array}{r}140 \\
(100 \\
413 \\
(274\end{array}$ & $\begin{array}{l}53 \cdot 3 \\
71 \cdot 4) \\
74 \cdot 7 \\
66 \cdot 3)\end{array}$ & 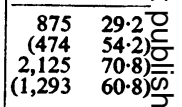 \\
\hline $\begin{array}{l}\text { Total } \\
\text { Incidence per } 1,000 \text { livebirths }\end{array}$ & $\begin{array}{cc}388 & 100 \cdot 0 \\
(190 & 49 \cdot 0) \\
25 \cdot 47\end{array}$ & $\begin{array}{cc}418 & 100 \cdot 0 \\
(209 & 50 \cdot 0) \\
25 \cdot 34\end{array}$ & $\begin{array}{c}476 \quad 100 \cdot 0 \\
(27958 \cdot 6) \\
27 \cdot 38\end{array}$ & $\begin{array}{cc}535 & 100 \cdot 0 \\
(321 & 60 \cdot 0) \\
29 \cdot 58\end{array}$ & $\begin{array}{l}630 \\
(394 \underset{32 \cdot 27}{62 \cdot 5}) \\
300 \cdot 0\end{array}$ & $\begin{array}{r}553 \\
(374 \\
24\end{array}$ & $\begin{array}{l}100 \cdot 0 \\
67 \cdot 6) \\
84\end{array}$ & $\begin{array}{c}3,000 \quad 100 \cdot 0 \\
(1,767 \\
27.53\end{array}$ \\
\hline
\end{tabular}

Secular trend: $\chi_{s}^{8}=29.7 ; P<0.001$

(Numbers of cases for whom questionnaires were completed are shown in parentheses)

therefore to be excluded from the analysis. Thus a total of 1,767 cases $(58.9 \%)$ were available for analysis, which was carried out using a SZAM computer made in the U.S.S.R. (Data relating to X-ray examination of the chest and abdomen, febrile and non-febrile diseases, drug consumption, vaginal bleeding during pregnancy, and abortions before and after pregnancy, were collected but are not included in this paper.)

3. The families of 150 male and 150 female randomly selected index patients, who had sibs, were visited personally, partly to check the information given and partly to collect further data for genetical studies to be published later. No serious discrepancies were discovered.

\section{RESULTS}

\section{INCIDENCE}

The incidence of $\mathrm{CDH}$ in livebirths in Budapest between 1962 and 1967 was 27.53 per 1,000 (Table I). The incidence increased from 1963 until 1966 and then dropped to a minimum in 1967. This fall is not likely to be due to under-ascertainment because almost $97 \%$ of cases are diagnosed during the first year of life and cases born in 1967 must also have been included in our 1969 survey. This surprising and unexplained fluctuation of incidence has been observed elsewhere (von Rosen, 1970) (Fig. 1).

The ratio of luxation-subluxation to dysplasia was 30:70. However, more than $70 \%$ of the index patients were diagnosed during the first six months when the severity of the condition cannot always be accurately assessed.

Of the total number of cases found, the number and percentage of those collected through questionnaires are shown in parentheses in Table I. These data suggest that the shorter the period between the date of birth and the date of the survey the better the cooperation $\left(\chi_{5}^{2}=40.37 ; P<0.001\right)$.

The 27.5 per 1,000 incidence of $\mathrm{CDH}$ found for Budapest is very high. Some sources of error (death of some infants before the condition could be diagnosed; migration; misdiagnosis) must be recog-

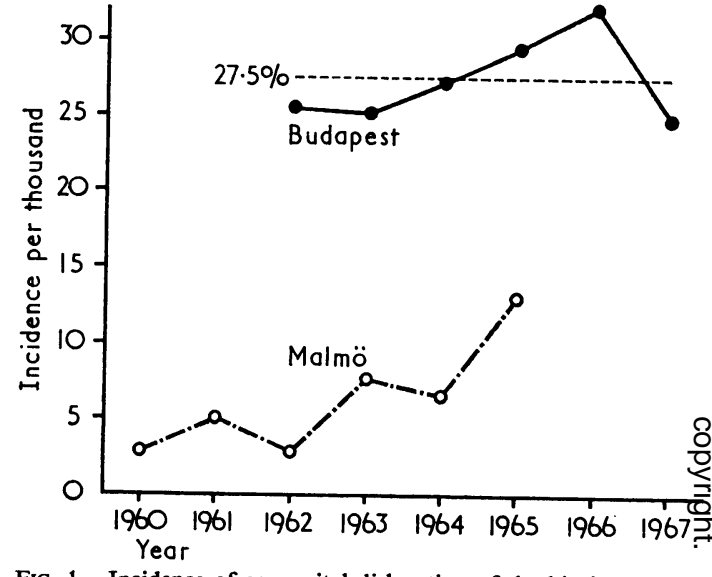

FIG. 1.-Incidence of congenital dislocation of the hip in Budapest, $1962-67$ and in Malmö, $1960-65$.

nized. But previous screening of newborn and infants $\stackrel{\mathbb{Q}}{\stackrel{2}{2}}$ in Hungary, though based on smaller numbers, resulted in similar (Bartha, 1968; Glauber, Koncz, Kullmann, and Vizkelety, 1970) or higher (Herczegh, 1962) values. This incidence is significantly higher than either the $1 \cdot 0-1 \cdot 5$ per 1,000 values given in $\frac{\varnothing}{\circ}$ the earlier literature or the $4 \cdot 0-6 \cdot 0$ per $1,000 ?$ values observed in recent screening programmes in 3 Sweden and England (Palmen, 1970; Wilson, 1964; Finlay, Maudsley, and Busfield, 1967; Edinburgh $\frac{\mathrm{O}}{3}$ Congenital Malformations Register, 1964-67).

Variations in incidence found in different coun- $\frac{}{2}$ tries and different surveys may be real (due, for $\rightarrow$ example, to ethnic differences or the custom of swaddling), but may be due to differences in the $N$ mode of ascertainment. These may arise from lack of uniformity in the definition of $\mathrm{CDH}$, variation in age of ascertainment, differences in screening methods, and thoroughness of the examination.

There has been only one previous study of inci- 0 dence in Hungary. Among a population of 12,000 schoolchildren in north-east Hungary between 1941 and 1952, Pap (1954) found an incidence of 10.5 per 1,000. Certain considerations suggest that the 
national value might have been somewhat lower than this, between 6 and 10 per 1,000 . The incidence of $\mathrm{CDH}$ in Hungary thus seems to be much higher than values observed in western European countries.

\section{Epidemiological Characteristics}

Side AfFeCTED. CDH occurred with about the same frequency on the right $(33.4 \%)$ and on the left $(35.2 \%)$ sides. The frequency of the bilateral cases was $31.4 \%$; it was higher in the luxationsubluxation group $(38.3 \%)$ than in the dysplasia group (28.5\%).

SeX Ratio. Only $25.6 \%$ were male. The deficiency of males was more apparent in the luxation-subluxation group $(18.6 \%)$ than in the dysplasia group $(28.5 \%)$.

MONTH OF BIRTH (Table II). There was a significant variation in incidence according to month of birth $\left(\chi_{11}^{2}=40.38 ; P<0.001\right)$. Incidence for each month from October to February was significantly higher than the average, with a maximum in January (26.5\% higher than the annual average). The lowest values were found in May and June (17.1-20.4\% less than the annual average). The monthly distribution of sex ratios showed no significant differences. The higher frequency of births with CDH during the winter months was first reported by Pap (1944). The seasonal variation in incidence produces an apparent association with monthly mean temperature (Fig. 2). There is, however, no consistent

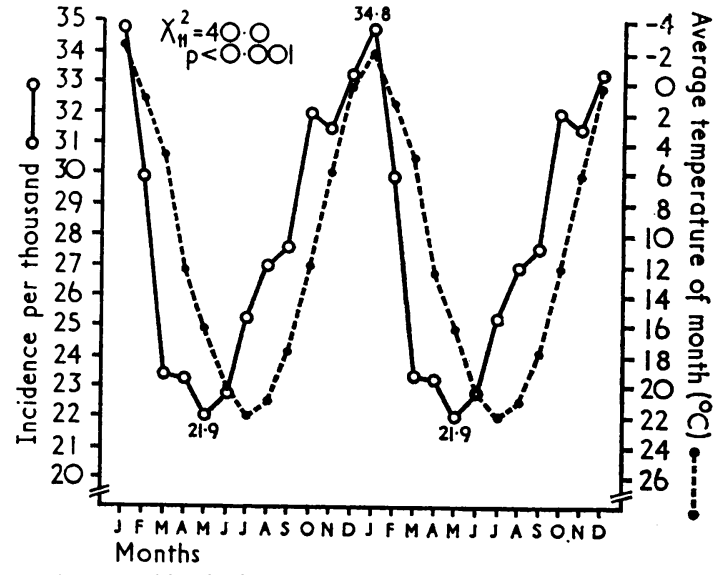

FIG. 2.-Monthly distribution of cases with congenital dislocation of the hip in Budapest, 1962-67.

correlation between incidence and temperature when data for the same month in various years are examined.

Associated Malformations (Table III). Of the $\mathrm{CDH}$ cases, $11.7 \%$ showed additional malformations. The higher rate of associated malformations $(17.8 \%)$ observed in males can be attributed mainly to the increased frequency of genital defects. Record and Edwards (1958) found associated malformations in $16 \%$ of index patients. These frequencies are significantly higher than those usually found at

TABLE II

MONTHLY DISTRIBUTION OF CASES WITH CONGENITAL DISLOCATION OF THE HIP

\begin{tabular}{|c|c|c|c|c|c|c|c|c|c|c|c|c|c|c|}
\hline \multirow{2}{*}{ Year } & & \multicolumn{13}{|c|}{ Month of Birth } \\
\hline & & Jan. & Feb. & Mar. & Apr. & May & Jun. & Jul. & Aug. & Sept. & Oct. & Nov. & Dec. & Total \\
\hline 1962 & $\begin{array}{l}\text { No. } \\
\% \text { \%o } \\
{ }^{\circ} \mathrm{C}\end{array}$ & $\begin{array}{r}40 \\
32.6 \\
+1.0\end{array}$ & $\begin{array}{l}30 \\
24 \cdot 4 \\
+1 \cdot 1\end{array}$ & $\begin{array}{c}21 \\
15.1 \\
+2.6\end{array}$ & $\begin{array}{r}32 \\
23.0 \\
+13.3\end{array}$ & $\begin{array}{r}20 \\
21 \cdot 7 \\
+15.2\end{array}$ & $\begin{array}{r}35 \\
26.8 \\
+18.5\end{array}$ & $\begin{array}{r}32 \\
23 \cdot 1 \\
+20.3\end{array}$ & $\begin{array}{r}28 \\
22.6 \\
+23.4\end{array}$ & $\begin{array}{r}38 \\
31.7 \\
+16.4\end{array}$ & $\begin{array}{r}31 \\
25.6 \\
+11.8\end{array}$ & $\begin{array}{l}40 \\
36 \cdot 3 \\
+6 \cdot 1\end{array}$ & $\begin{array}{l}31 \\
26.6 \\
-1.6\end{array}$ & $\begin{array}{l}388 \\
25 \cdot 5\end{array}$ \\
\hline 1963 & $\begin{array}{l}\text { No. } \\
\% \% \\
\%\end{array}$ & $\begin{array}{l}57 \\
42 \cdot 3 \\
-5 \cdot 2\end{array}$ & $\begin{array}{l}41 \\
30 \cdot 4 \\
-3 \cdot 2\end{array}$ & $\begin{array}{l}25 \\
16.9 \\
+3.5\end{array}$ & $\begin{array}{r}22 \\
15 \cdot 3 \\
+13 \cdot 1\end{array}$ & $\begin{array}{r}28 \\
17.9 \\
+17.4\end{array}$ & $\begin{array}{r}36 \\
24 \cdot 5 \\
+21 \cdot 1\end{array}$ & $\begin{array}{r}30 \\
21 \cdot 1 \\
+23.8\end{array}$ & $\begin{array}{r}27 \\
20.3 \\
+21.8\end{array}$ & $\begin{array}{r}33 \\
24 \cdot 7 \\
+18.0\end{array}$ & $\begin{array}{r}33 \\
26.5 \\
+11.2\end{array}$ & $\begin{array}{c}39 \\
31.8 \\
+9.2\end{array}$ & $\begin{array}{l}47 \\
36 \cdot 1 \\
-3 \cdot 2\end{array}$ & $\begin{array}{l}418 \\
25 \cdot 3\end{array}$ \\
\hline 1964 & $\begin{array}{l}\text { No. } \\
\text { \%oo } \\
{ }^{\circ} \mathbf{C}\end{array}$ & $\begin{array}{l}47 \\
32 \cdot 1 \\
-5 \cdot 7\end{array}$ & $\begin{array}{c}41 \\
29.5 \\
+0.9\end{array}$ & $\begin{array}{c}41 \\
25 \cdot 7 \\
+3 \cdot 3\end{array}$ & $\begin{array}{r}33 \\
22.0 \\
+12.8\end{array}$ & $\begin{array}{r}39 \\
24.3 \\
+16.5\end{array}$ & $\begin{array}{r}28 \\
18.9 \\
+22.9\end{array}$ & $\begin{array}{r}35 \\
22.7 \\
+22.4\end{array}$ & $\begin{array}{r}35 \\
24.8 \\
+19.9\end{array}$ & $\begin{array}{r}37 \\
27.8 \\
+16.7\end{array}$ & $\begin{array}{r}46 \\
33.4 \\
+11.0\end{array}$ & $\begin{array}{l}46 \\
36 \cdot 3 \\
+7 \cdot 6\end{array}$ & $\begin{array}{c}48 \\
34 \cdot 1 \\
+0.8\end{array}$ & $\begin{array}{r}476 \\
27 \cdot 4\end{array}$ \\
\hline 1965 & $\begin{array}{l}\text { No. } \\
\text { \%oo } \\
{ }^{\circ} \mathrm{C}\end{array}$ & $\begin{array}{c}64 \\
42.4 \\
+0.8\end{array}$ & $\begin{array}{l}44 \\
31 \cdot 2 \\
-1 \cdot 4\end{array}$ & $\begin{array}{l}38 \\
23.9 \\
+6.2\end{array}$ & $\begin{array}{r}48 \\
31.6 \\
+10.2\end{array}$ & $\begin{array}{c}39 \\
22.2 \\
\times 15.0\end{array}$ & $\begin{array}{r}47 \\
29.9 \\
+19.4\end{array}$ & $\begin{array}{c}38 \\
24 \cdot 2 \\
+20.8\end{array}$ & $\begin{array}{r}45 \\
29.7 \\
+19.2\end{array}$ & $\begin{array}{r}40 \\
26 \cdot 7 \\
+17 \cdot 1\end{array}$ & $\begin{array}{r}39 \\
27.5 \\
+10.4\end{array}$ & $\begin{array}{c}44 \\
32 \cdot 5 \\
+3.0\end{array}$ & $\begin{array}{l}49 \\
35.8 \\
+2.0\end{array}$ & $\begin{array}{l}535 \\
29 \cdot 6\end{array}$ \\
\hline 1966 & $\begin{array}{l}\text { No. } \\
\text { \%oo } \\
{ }^{\circ} \mathbf{C}\end{array}$ & $\begin{array}{l}49 \\
32 \cdot 2 \\
-3 \cdot 0\end{array}$ & $\begin{array}{c}56 \\
37 \cdot 1 \\
+7 \cdot 1\end{array}$ & $\begin{array}{c}54 \\
29.2 \\
+6.6\end{array}$ & $\begin{array}{r}49 \\
28 \cdot 3 \\
+13.6\end{array}$ & $\begin{array}{r}40 \\
22 \cdot 7 \\
+17.0\end{array}$ & $\begin{array}{r}35 \\
20.3 \\
+19.9\end{array}$ & $\begin{array}{r}55 \\
31 \cdot 6 \\
+20.7\end{array}$ & $\begin{array}{r}51 \\
32.1 \\
+20.2\end{array}$ & $\begin{array}{r}54 \\
35.8 \\
+16.8\end{array}$ & $\begin{array}{r}72 \\
47 \cdot 1 \\
+15 \cdot 3\end{array}$ & $\begin{array}{c}42 \\
28.9 \\
+5.5\end{array}$ & $\begin{array}{c}73 \\
44 \cdot 8 \\
+2 \cdot 4\end{array}$ & $\begin{array}{r}631 \\
32 \cdot 3\end{array}$ \\
\hline 1967 & $\begin{array}{l}\text { No. } \\
\text { \%oo } \\
{ }^{\circ} \mathrm{C}\end{array}$ & $\begin{array}{r}51 \\
28 \cdot 3 \\
+2 \cdot 4 \\
\end{array}$ & $\begin{array}{r}42 \\
25.5 \\
+7.6 \\
\end{array}$ & $\begin{array}{r}49 \\
26.9 \\
+11.3 \\
\end{array}$ & $\begin{array}{r}35 \\
19.3 \\
+16.9 \\
\end{array}$ & $\begin{array}{r}43 \\
24 \cdot 7 \\
+16.9 \\
\end{array}$ & $\begin{array}{r}33 \\
18.0 \\
+19.3 \\
\end{array}$ & $\begin{array}{r}52 \\
26.8 \\
+23.4 \\
\end{array}$ & $\begin{array}{r}56 \\
29.7 \\
+21.4 \\
\end{array}$ & $\begin{array}{r}41 \\
21 \cdot 2 \\
+18 \cdot 4 \\
\end{array}$ & $\begin{array}{r}56 \\
30.1 \\
+12.8 \\
\end{array}$ & $\begin{array}{l}48 \\
26.7 \\
+5 \cdot 3\end{array}$ & $\begin{array}{r}47 \\
23.6 \\
+0.8 \\
\end{array}$ & $\begin{array}{c}552 \\
24 \cdot 8\end{array}$ \\
\hline Total & $\begin{array}{l}\text { No. } \\
\% \% \\
\% \text { \% }\end{array}$ & $\begin{array}{l}308 \\
34 \cdot 8 \\
-2 \cdot 2\end{array}$ & $\begin{array}{r}254 \\
29.9 \\
+1.2\end{array}$ & $\begin{array}{r}228 \\
23.4 \\
+5.0\end{array}$ & $\begin{array}{r}219 \\
23.3 \\
+12.4\end{array}$ & $\begin{array}{r}219 \\
21.9 \\
+16.3\end{array}$ & $\begin{array}{r}214 \\
22 \cdot 8 \\
+20 \cdot 2\end{array}$ & $\begin{array}{r}242 \\
25.2 \\
+21.9\end{array}$ & $\begin{array}{r}242 \\
26.9 \\
+21.0\end{array}$ & $\begin{array}{r}243 \\
27.6 \\
+17.7\end{array}$ & $\begin{array}{r}277 \\
32 \cdot 1 \\
+12.1\end{array}$ & $\begin{array}{r}259 \\
31.6 \\
+6.1\end{array}$ & $\begin{array}{r}295 \\
33 \cdot 3 \\
+0.2 \\
\end{array}$ & $\begin{array}{r}3,000 \\
27 \cdot 5\end{array}$ \\
\hline $\begin{array}{l}\text { Sex ratio } \\
\text { (\% male) }\end{array}$ & & $26 \cdot 0$ & $26 \cdot 0$ & $25 \cdot 0$ & $28 \cdot 8$ & $26 \cdot 9$ & $27 \cdot 6$ & $27 \cdot 3$ & $26 \cdot 4$ & $25 \cdot 1$ & $25 \cdot 3$ & $21 \cdot 2$ & $23 \cdot 4$ & $25 \cdot 6$ \\
\hline
\end{tabular}


TABLE III

ASSOCIATED DEFECTS OCCURRING AMONG 1,767 PROPOSITI

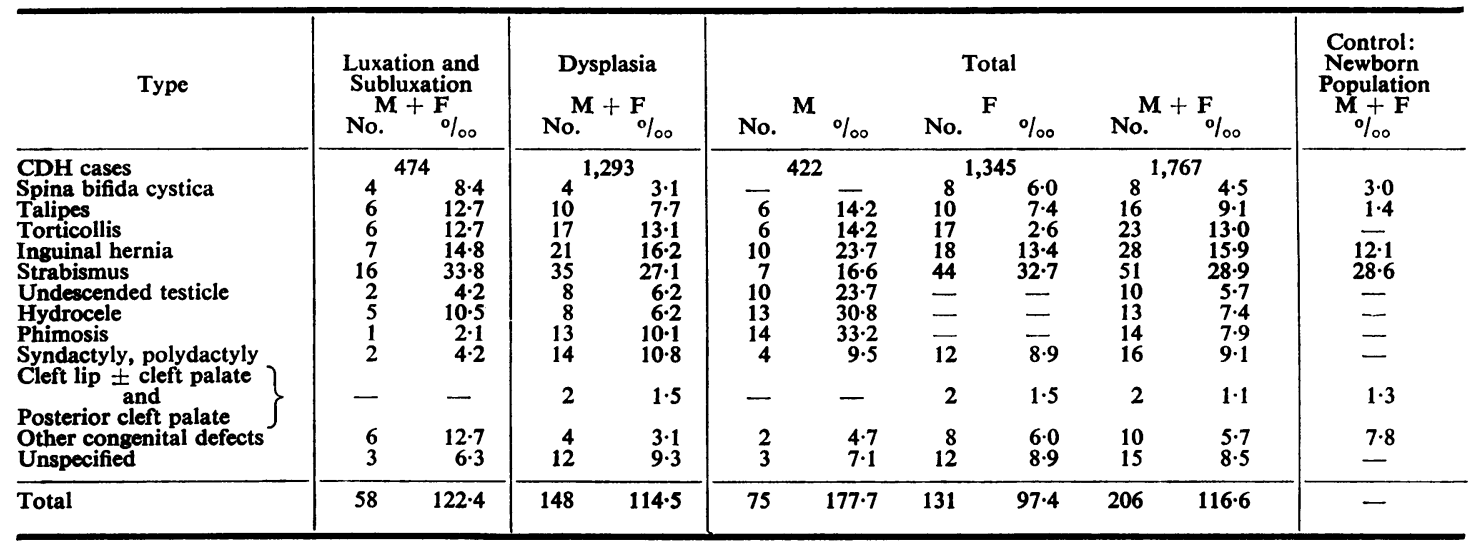

TABLE IV

BIRTH WEIGHT DISTRIBUTION OF NEWBORN WITH CONGENITAL DISLOCATION OF THE HIP

\begin{tabular}{|c|c|c|c|c|c|c|c|c|c|c|c|c|}
\hline \multirow[b]{2}{*}{ Sex } & \multirow[b]{2}{*}{ Type } & \multicolumn{7}{|c|}{ Birth Weight (g) } & \multirow[b]{2}{*}{ Total } & \multirow[b]{2}{*}{$\begin{array}{c}\text { Average } \\
\text { Birth } \\
\text { Weight } \\
\text { (g) }\end{array}$} & \multirow[b]{2}{*}{$\underset{\text { known }}{\text { Un- }}$} & \multirow[b]{2}{*}{ Total } \\
\hline & & $\begin{array}{l}<1,499 \\
\text { No. } \%\end{array}$ & $\begin{array}{l}1,500- \\
1,999 \\
\text { No. } \%\end{array}$ & $\begin{array}{l}2,000- \\
2,499 \\
\text { No. } \%\end{array}$ & $\begin{array}{l}2,500- \\
2,999 \\
\text { No. } \%\end{array}$ & $\begin{array}{l}3,000- \\
3,499 \\
\text { No. } \%\end{array}$ & $\begin{array}{c}3,500- \\
3,999 \\
\text { No. } \%\end{array}$ & $\begin{array}{l}4,000 \\
\text { and over } \\
\text { No. } \%\end{array}$ & & & & \\
\hline \multirow[t]{3}{*}{$\mathbf{M}$} & Dysplasia & 20.6 & $113 \cdot 2$ & $247 \cdot 0$ & 7120.6 & $11834 \cdot 3$ & 8925.9 & $298 \cdot 4$ & 344 & 3,237 & 3 & \\
\hline & $\begin{array}{l}\text { Subluxation/ } \\
\text { luxation } \\
\text { Total (CDH) }\end{array}$ & - 2. $\overline{0.5}$ & $\begin{array}{rr}4 & 5 \cdot 5 \\
15 & 3.6\end{array}$ & $\begin{array}{rr}2 & 2 \cdot 7 \\
26 & 6 \cdot 2\end{array}$ & $\begin{array}{ll}15 & 20.6 \\
86 & 20.6\end{array}$ & $\begin{array}{rr}23 & 31 \cdot 5 \\
141 & 33 \cdot 8\end{array}$ & $\begin{array}{rr}21 & 28.9 \\
110 & 26.4\end{array}$ & $\begin{array}{rr}8 & 11.0 \\
37 & 8.9\end{array}$ & $\begin{array}{r}73 \\
417\end{array}$ & $\begin{array}{l}3,298 \\
3,248\end{array}$ & $\begin{array}{l}2 \\
5\end{array}$ & 422 \\
\hline & Control & $1,5322 \cdot 7$ & $1,4432 \cdot 6$ & $3,476 \quad 6 \cdot 2$ & $10,86319 \cdot 2$ & $21,44738 \cdot 0$ & $13,720 \quad 24 \cdot 33$ & $3,991 \quad 7 \cdot 1$ & 56,472 & 3,217 & 2 & 56,474 \\
\hline \multirow[t]{3}{*}{$\mathbf{F}$} & Dysplasia & $111 \cdot 2$ & $283 \cdot 0$ & $72 \quad 7 \cdot 7$ & $19220 \cdot 4$ & $375 \quad 39.9$ & $22423 \cdot 8$ & $384 \cdot 1$ & 940 & 3,163 & 6 & 946 \\
\hline & $\begin{array}{l}\text { luxation } \\
\text { Total (CDH) }\end{array}$ & $\begin{array}{rr}8 & 2.0 \\
19 & 1.4\end{array}$ & $\begin{array}{rr}8 & 2 \cdot 0 \\
36 & 2 \cdot 7\end{array}$ & $\begin{array}{rr}38 & 9 \cdot 7 \\
110 & 8 \cdot 3\end{array}$ & $\begin{array}{ll}129 & 32 \cdot 8 \\
321 & 24 \cdot 1\end{array}$ & $\begin{array}{ll}134 & 34 \cdot 1 \\
509 & 38 \cdot 2\end{array}$ & $\begin{array}{rr}69 & 17 \cdot 6 \\
293 & 22 \cdot 0\end{array}$ & $\begin{array}{rr}7 & 1 \cdot 8 \\
45 & 3 \cdot 2\end{array}$ & $\begin{array}{r}393 \\
1,333\end{array}$ & $\begin{array}{l}3,027 \\
3,123\end{array}$ & $\begin{array}{r}6 \\
12\end{array}$ & $\begin{array}{r}399 \\
1,345\end{array}$ \\
\hline & Control & $1,5533.01$ & $1,481 \quad 2 \cdot 8$ & $3,890 \quad 7 \cdot 4$ & $13,61825.92$ & $0,72439 \cdot 5$ & $9,426 \quad 18.01$ & $1,798 \quad 3 \cdot 4$ & 52,490 & 3,081 & 2 & 52,492 \\
\hline
\end{tabular}

birth. This difference may be due partly to the fact that strabismus, congenital inguinal hernia, hydrocele, and phimosis, which occur fairly frequently are often overlooked. The more frequent occurrence of certain malformations (e.g., spina bifida) may be due to chance. Lorenz (1920) described the association of $\mathrm{CDH}$ with talipes and torticollis. This suggests the possible importance of intrauterine mechanical effects; the frequency of breech presentation is also significantly higher in each of the three malformation types. The possibility of a functional muscular weakness which could, for example, explain the more frequent occurrence of inguinal hernia, cannot be excluded either. For certain malformations (e.g., hydrocele), no incidence values in the Hungarian population are available, and therefore it is impossible to tell whether the frequency found in the CDH cases is higher than usual. On the other hand, the frequency of malformations, such as cleft lip with or without cleft palate, and posterior cleft palate, is no higher than in the general population.

TyPe OF Delivery. Of the CDH cases, $11.4 \%$ were breech deliveries; the frequency of breech presentation for all births was only $3.1 \%(P<0.001)$. The sex ratio of CDH cases born by the breech (29.9\% males) was higher than in those born after a vertex presentation $(23.6 \%)$. The proportion of cases delivered by Caesarean section did not differ significantly from the control value.

FreQUENCY OF TWIN BIRTHS. There were 21 twin births. This gives a frequency of $1.2 \%$ which is not significantly different from that expected $(1.0 \%)$.

BIRTH WEIGHT (Table IV). The weight distribution of both the male and the female $\mathrm{CDH}$ group showed significant differences when compared to that of the control group (male: $\chi_{6}^{2}=14.4 ; P<0.05$; female: $\left.\chi_{6}^{2}=26.3 ; P<0.001\right)$. A considerable part of this difference may be attributed to the greater frequency of infants weighing less than $1,500 \mathrm{~g}$ among the 


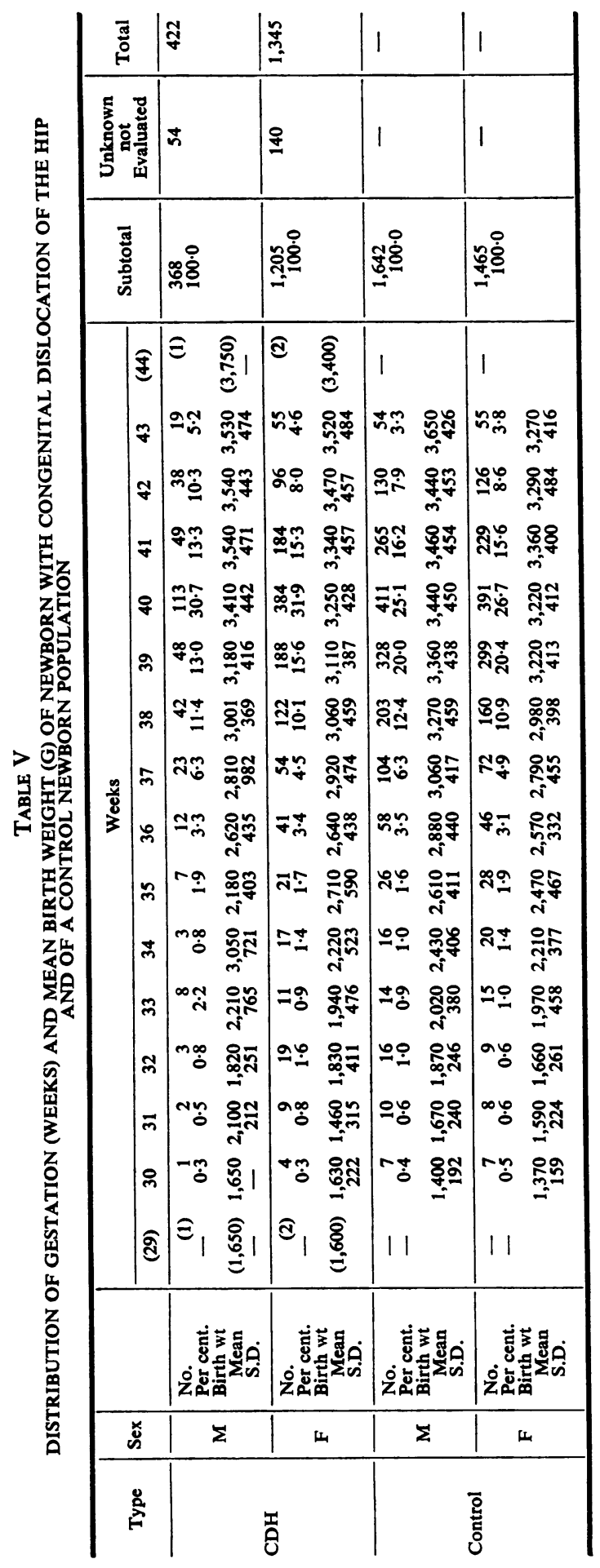

controls. The low frequency of $\mathrm{CDH}$ among those of birth weight under $1,500 \mathrm{~g}$ may be due to the fact that $\mathrm{CDH}$ would not have been diagnosed if they had died and that early death is more likely when birth weight is low. Excluding the group under 1,500 $\mathrm{g}$, only females show a significant difference (male: $\chi_{5}^{2}=6.4 ; P>0.05$; female: $\left.\chi_{5}^{2}=15.1 ; P<0.01\right)$. The average birth weight of the $\mathrm{CDH}$ group also exceeds that of the control group in spite of the fact that it contains a higher proportion of first births and of breech presentations.

Gestation Period (Table V). Gestation period was calculated in weeks by the method of Naegele from the first day of the last menses (284 cases), from the expected date of birth (1,004 cases) or from both (285 cases). The reliability of the data given on the questionnaires is, of course, dubious. As control values for Budapest were not available, data found in one of the provincial cities in Hungary were used as controls (Fekete et al., 1968). The average birth weight of the newborn was slightly higher in this city than in the capital. The duration of gestation was significantly longer in $\mathrm{CDH}$ cases for both males $\left(\chi_{13}^{2}=23.5 ; P<0.05\right)$ and females $\left(\chi_{13}^{2}=23.6\right.$; $P<0.05)$ than in control infants though the differences were not large.

BirTH ORder (Table VI). The incidence is significantly higher in first births $\left(\chi_{1}^{2}=20.1 ; P<0.001\right)$ and this is independent of maternal age. The frequency of breech presentation is not significantly higher in first births $(11.9 \%)$ than in later births $(9.1 \%)\left(\chi_{1}^{2}=2.7 ; P>0.05\right)$ and thus cannot account for the primogeniture effect.

The pregnancy order distribution of the CDH cases which takes account of still births and abortions was as follows: $1=47.4 \% ; 2=24.0 \% ; 3=$ $13.6 \% ; 4=7 \cdot 3 \% ; 5=3.6 \% ; 6-7=2.5 \% ; 8-=$ $1.6 \%$. No similar data are available for a control group and in our experience information given concerning the number of induced and spontaneous abortions is fairly inaccurate. It is therefore difficult to judge the considerable difference found in the frequency of first births $(72 \cdot 7 \%)$ and first pregnancies $(47 \cdot 4 \%)$.

MATERnal Age (Table VI). The average maternal age was 0.5 years higher for the $\mathrm{CDH}$ group than for the controls. It is worth noting that the incidence of CDH is somewhat higher than expected among infants of mothers aged 40 and over. Record and Edwards (1958) also observed a more frequent occurrence of $\mathrm{CDH}$ in babies born to mothers above 35.

Paternal Age. No significant differences were noted. 
TABLE VI

OBSERVED (O) AND EXPECTED (E) NUMBERS, AND INCIDENCE PER 1,000 LIVEBIRTHS, OF CONGENITAL DISLOCATION OF THE HIP ACCORDING TO BIRTH ORDER AND MATERNAL AGE

\begin{tabular}{|c|c|c|c|c|c|c|c|c|c|c|c|c|c|c|c|c|c|}
\hline \multirow[b]{2}{*}{$\begin{array}{l}\text { Age } \\
\text { Group }\end{array}$} & \multicolumn{12}{|c|}{ Birth Order } & \multicolumn{3}{|c|}{ Total } & \multicolumn{2}{|c|}{ Control } \\
\hline & $\mathrm{O} / \mathrm{E}$ & $\%$ & $\mathrm{O} / \mathrm{E}$ & $1 / 00$ & $\mathrm{O} / \mathrm{E}^{3}$ & $\%$ & $O / E^{4}$ & $0 / 00$ & $O / E^{5}$ & $5 \%$ & $O / \mathrm{E}^{6-}$ & $\%$ & $\mathrm{O} / \mathrm{E}$ & $0 / 2$ & Per cent. & No. & $\%$ \\
\hline$<19$ & $\frac{108}{179}$ & $9 \cdot 8$ & $\frac{1}{12}$ & $1 \cdot 3$ & $\frac{0}{1}$ & - & - & & - & & - & & $\frac{109}{192}$ & $9 \cdot 2$ & $6 \cdot 1$ & 11,872 & 10.9 \\
\hline $20-24$ & $\frac{631}{573}$ & $17 \cdot 8$ & $\frac{101}{125}$ & $13 \cdot 1$ & $\frac{11}{16}$ & $11 \cdot 2$ & $\frac{0}{4}$ & 0.0 & $\frac{0}{1}$ & 0.0 & -- & & $\frac{743}{719}$ & $16 \cdot 7$ & $42 \cdot 0$ & 44,421 & $40 \cdot 8$ \\
\hline $25-29$ & $\frac{377}{268}$ & $22 \cdot 8$ & $\frac{134}{179}$ & $12 \cdot 1$ & $\frac{24}{35}$ & $11 \cdot 3$ & $\frac{5}{10}$ & $8 \cdot 0$ & $\frac{1}{4}$ & $3 \cdot 7$ & $\frac{1}{3}$ & $5 \cdot 4$ & $\frac{542}{499}$ & $17 \cdot 6$ & $30 \cdot 7$ & 30,755 & $28 \cdot 2$ \\
\hline $30-34$ & $\frac{133}{81}$ & $26 \cdot 5$ & $\frac{97}{101}$ & $15 \cdot 6$ & $\frac{20}{33}$ & $9 \cdot 7$ & $\frac{7}{13}$ & $9 \cdot 1$ & $\frac{1}{6}$ & $3 \cdot 0$ & $\frac{1}{7}$ & $2 \cdot 3$ & $\frac{259}{242}$ & $17 \cdot 4$ & $14 \cdot 8$ & 14,850 & $13 \cdot 6$ \\
\hline $35-39$ & $\frac{24}{26}$ & $15 \cdot 1$ & $\frac{36}{30}$ & $19 \cdot 6$ & $\frac{12}{16}$ & $12 \cdot 0$ & $\frac{3}{9}$ & $5 \cdot 3$ & $\frac{1}{4}$ & $3 \cdot 8$ & $\frac{6}{8}$ & $12 \cdot 6$ & $\frac{82}{93}$ & $14 \cdot 3$ & $4 \cdot 6$ & 5,734 & $5 \cdot 3$ \\
\hline $40-$ & $\frac{12}{7}$ & $33 \cdot 5$ & $\frac{7}{5}$ & $23 \cdot 3$ & $\frac{7}{4}$ & $29 \cdot 8$ & $\frac{1}{2}$ & $7 \cdot 0$ & $\frac{2}{2}$ & $18 \cdot 7$ & $\frac{3}{3}$ & $15 \cdot 6$ & $\frac{32}{23}$ & $24 \cdot 0$ & $1 \cdot 8$ & 1,334 & $1 \cdot 2$ \\
\hline $\begin{array}{l}\text { Total } \\
\%\end{array}$ & $\frac{1,285}{1,134}$ & $\begin{array}{l}18 \cdot 4 \\
2 \cdot 7\end{array}$ & $\frac{376}{452}$ & $\begin{array}{r}13 \cdot 5 \\
21 \cdot 3\end{array}$ & $\frac{74}{105}$ & $\begin{array}{l}11 \cdot 5 \\
4 \cdot 2\end{array}$ & $\begin{array}{l}16 \\
38\end{array}$ & $\begin{array}{l}6.8 \\
0.9\end{array}$ & $\frac{5}{17}$ & $\begin{array}{l}4 \cdot 8 \\
0 \cdot 3\end{array}$ & $\frac{11}{21}$ & $\begin{array}{r}8 \cdot 3 \\
0.6\end{array}$ & $\frac{1,767}{1,767}$ & $\begin{array}{r}16 \cdot 2 \\
10\end{array}$ & $\begin{array}{l}100 \cdot 0 \\
0.0\end{array}$ & $\begin{array}{c}\text { Mean b } \\
\text { of affec } \\
=-\end{array}$ & $\begin{array}{l}\text { th order } \\
37\end{array}$ \\
\hline $\begin{array}{c}\text { Control } \\
\text { No. } \\
\%\end{array}$ & 69,9 & 64 & 27 , & $\begin{array}{l}99 \\
25 \cdot 6\end{array}$ & 6,4 & $\begin{array}{l}5 \\
5 \cdot 9\end{array}$ & 2,34 & $\begin{array}{l}15 \\
2 \cdot 1\end{array}$ & 1,03 & $1 \cdot 0$ & 1,325 & $1 \cdot 2$ & & $\begin{array}{r}108,96 \\
10\end{array}$ & 6 & $\begin{array}{l}\text { Mean } b \\
\text { of cont }\end{array}$ & $\begin{array}{l}\text { th order } \\
\text { Is } \\
54\end{array}$ \\
\hline
\end{tabular}

TABLE VII

OCCUPATION OF PARENTS OF INDEX PATIENTS WITH CONGENITAL DISLOCATION OF THE HIP

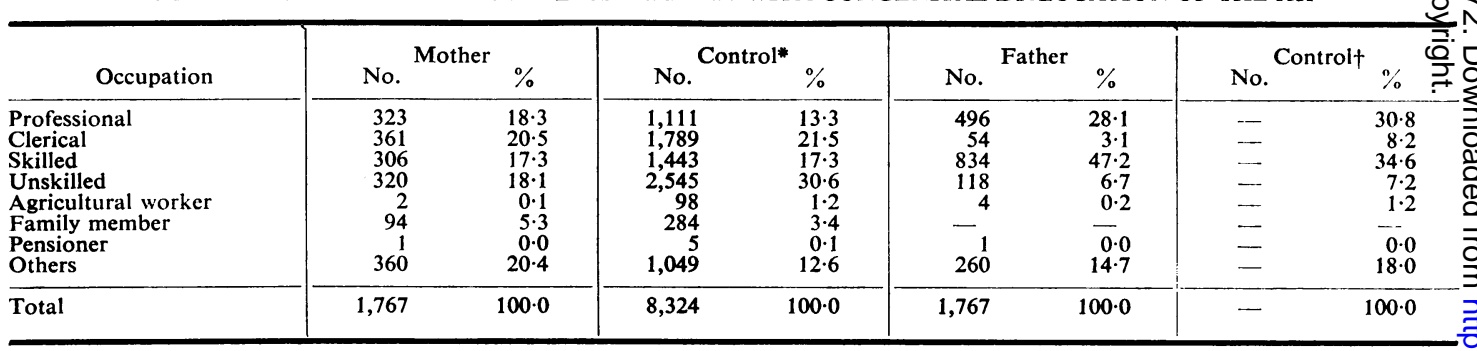

*Data cited from The Hungarian Planned Parenthood Investigation, 1970

†Data taken from Hungarian Demographic Yearbooks

TABLE VIII

AGE AT DIAGNOSIS AND TREATMENT OF CONGENITAL DISLOCATION OF THE HIP

\begin{tabular}{|c|c|c|c|c|c|c|c|c|c|c|}
\hline $\begin{array}{c}\text { Age at } \\
\text { Diagnosis } \\
\text { (mth) }\end{array}$ & $\begin{array}{l}\text { Pavlik's } \\
\text { Stirrup }\end{array}$ & $\begin{array}{l}\text { Frejka } \\
\text { Pillow }\end{array}$ & $\begin{array}{l}\text { Abduction } \\
\text { Splint }\end{array}$ & $\begin{array}{l}\text { Combined } \\
\text { Treatment }\end{array}$ & $\begin{array}{l}\text { Plaster } \\
\text { Cast }\end{array}$ & $\begin{array}{l}\text { Adductor } \\
\text { Tenotomy }\end{array}$ & Operation & Unknown & $\begin{array}{l}\text { Tota } \\
\text { No. }\end{array}$ & al $\%$ \\
\hline $\begin{array}{l}\text { At birth } \\
0-3 \\
4-5 \\
6-7 \\
8-9 \\
10-11 \\
\text { After } 1 \text { yr } \\
\text { Unknown }\end{array}$ & $\begin{array}{r}5 \\
192 \\
146 \\
90 \\
16 \\
10 \\
6 \\
1\end{array}$ & $\begin{array}{r}12 \\
319 \\
271 \\
123 \\
32 \\
10 \\
6 \\
3\end{array}$ & $\begin{array}{r}10 \\
10 \\
7 \\
2 \\
1 \\
5 \\
\end{array}$ & $\begin{array}{r}20 \\
160 \\
115 \\
78 \\
20 \\
16 \\
21 \\
3\end{array}$ & $\begin{array}{l}1 \\
2 \\
5 \\
3 \\
2 \\
1 \\
7 \\
1\end{array}$ & $\begin{array}{l}- \\
- \\
\overline{-} \\
\overline{-}\end{array}$ & $\begin{array}{l}E \\
E \\
z \\
-\end{array}$ & $\begin{array}{r}1 \\
5 \\
4 \\
6 \\
1 \\
2 \\
13\end{array}$ & $\begin{array}{r}39 \\
688 \\
551 \\
307 \\
73 \\
26 \\
43 \\
21\end{array}$ & $\begin{array}{r}2.21 \\
38.94 \\
31 \cdot 28 \\
17 \cdot 47 \\
4 \cdot 13 \\
1 \cdot 57 \\
2.43 \\
1 \cdot 29\end{array}$ \\
\hline Total No. & $\begin{array}{l}466 \\
26 \cdot 47\end{array}$ & $\begin{array}{l}776 \\
43.92\end{array}$ & $\begin{array}{l}35 \\
2.08\end{array}$ & $\begin{array}{l}432 \\
24 \cdot 45\end{array}$ & 22 & $\begin{array}{l}1 \\
0 \cdot 16\end{array}$ & $\begin{array}{l}3 \\
0 \cdot 26\end{array}$ & $\begin{array}{l}32 \\
1.82\end{array}$ & 1,767 & $\begin{array}{l}100 \cdot 00 \\
100 \cdot 00\end{array}$ \\
\hline
\end{tabular}

Social Position (Table VII). Of the numerous indices of social circumstances that could have been considered, occupation was chosen as the most useful. The distribution of mothers of $\mathrm{CDH}$ infants differed significantly from that of the control group $\left(\chi_{7}^{2}=199 \cdot 3 ; P<0 \cdot 001\right)$. This was due mainly to the higher proportion of women in the professional ando 'other' groups, and the lower proportion of unskilledo 
manual workers among the $\mathrm{CDH}$ mothers. WynneDavies (1970b) also noted a higher incidence of $\mathrm{CDH}$ in families living under better social conditions.

\section{Clinical Data}

Time of Diagnosis. Of the CDH cases, $41 \cdot 2 \%$ were diagnosed during the first three months, and $72 \cdot 4 \%$ during the first six months (Table VIII).

Method of TReatment (Table VIII). Though the Pavlik stirrup is to-day considered more effective than the Frejka pillow, the latter was more extensively used during the period studied. For the past few years, most departments have used the Pavlik stirrup to treat babies under 6 months of age. The relatively high number of those receiving combined treatment is a result either of a change in treatment due to the growth and development of the child, or of the need to operate on those children who failed to respond to conservative treatment. Treatment by tenotomy or by other operation alone was carried out only on the few patients who first came for treatment after the age of 12 months.

\section{CONClusions}

The recorded incidence of CDH of 27.53 per 1,000 in Budapest infants is conspicuously high. It could be a true representation of the actual incidence or it could be the result of overdiagnosis brought about by the extensive use of screening tests. In order to estimate this, the sex ratio was compared with that reported by Record and Edwards (1958) whose series undoubtedly contained only cases of luxation of the hip. Using a polygenic-multifactorial model, it is assumed that the liability to $\mathrm{CDH}$ shows a normal standard distribution. Thus at a given population frequency (p), the threshold (L) above which $\mathrm{CDH}$ appears in the individuals studied, may be estimated. The values of $L$ can thus be calculated from the sex ratios for the Birmingham and for the Budapest data (male 3.57, female 3.09 for Birmingham; male 2.2, female 1.75 for Budapest). (The value of $L$ for a given $p$ can be calculated by $\phi L=$ 1-p.) The difference between Birmingham and Budapest is therefore 1.37 for males and 1.34 for females. These values are surprisingly near to each other. The liability, i.e., the threshold of males, is 0.5 lower than that of females in both cities and thus the threshold of the overall population is $3 \cdot 1$ in Birmingham and 1.7 in Budapest (Fig. 3). This reflects the differences between the methods of diagnosis used in the present series in Budapest (neonatal diagnosis) and those used previously in Birmingham (late diagnosis). Diagnosis in the neonatal period may lead to the identification of a number of mild cases, most of whom would recover

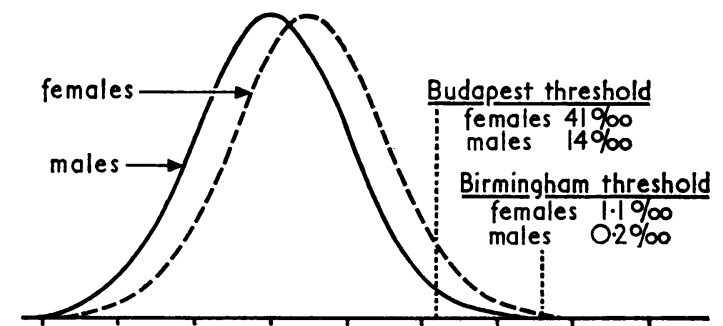

FIG. 3.-Sex differences and threshold shift in data obtained in Budapest and in Birmingham.

spontaneously. To apply active treatment to such cases would be a less serious error than failing to treat established cases of the defect. Nevertheless, in view of the frequency of spontaneous recovery of the unstable hip, orthopaedic treatment other than maintaining abduction by swaddling should not be resorted to unless signs of $\mathrm{CDH}$ are still present at the age of 4 weeks.

Infants with $\mathrm{CDH}$ show no evidence of general impairment of prenatal development. Birth weight, which is a sensitive indicator of fetal development, is not lower than for normal babies. Apart from teratological dislocations and some rather rare cases, dislocation does not exist at birth. $\mathrm{CDH}$ is thus an anomaly not primarily congenital, but rather the postnatal manifestation of a liability which is congenital. Support for this view comes from geographical and ethnic differences (Wessel, 1918; Corrigan and Segal, 1950; Getz, 1955; Kraus and Schwartzmann, 1957; Coleman, 1968; Salter, 1968) and in differences in the custom of swaddling, as well as seasonal variations of incidence (Pap, 1944; Nagura, 1955, 1960; Record and Edwards, 1958; Andrén and Palmen, 1963; Weissman and Salama, 1966; Chen, Weissman, Salama, and Klingberg, 1970).

Certain prenatal factors may influence the postnatal development of $\mathrm{CDH}$. Hormonal effects acting on the pelvis and on the hip joint of female fetuses during the terminal phase of pregnancy induce a laxity in both the articular capsule and ligamentum teres (Andrén, 1960, 1962) which, especially if associated with a breech presentation (Wilkinson, 1963; 1966) may cause the femoral head to assume a malposition. The more frequent occurrence of $\mathrm{CDH}$ in infants born after a longer than normal gestation indicates the importance of hormonal effects during the terminal weeks of pregnancy. The greater frequency of $\mathrm{CDH}$ in infants of high birth weight may explain the higher incidence in children of mothers living in good socio-economic conditions. 


\section{SUMmary}

The incidence of congenital dislocation of the hip (which received orthopaedic treatment) among 108,966 Budapest infants born in the period 1962 to 1967 was 27.53 per 1,000 live births. Of those affected, $41 \cdot 2 \%$ were diagnosed during the first three months and $72.4 \%$ were diagnosed by 6 months of age. The high incidence was due in part to the inclusion of many mild cases detected by extensive screening of the newborn. The right hip only was affected in $33.4 \%$, the left in $35.2 \%$, and both hips in $31.4 \%$. The percentage of males was 25.6. Incidence among children born in the months of October to February was significantly higher than the incidence of those born during the rest of the year. Associated malformations were present in $11.7 \%$ of cases. Of index patients, $11.4 \%$ were breech presentations. The frequency of twins $(1.2 \%)$ did not differ markedly from the control value $(1.0 \%)$. The defect was more frequent among infants of high birth weight and in those born after a long gestation period. The occurrence was signicantly higher in first births, in infants of mothers above 40 years of age, and in those in better social circumstances.

\section{REFERENCES}

ANDRÉN, L. (1960). Instability of the pelvic symphysis and congenital dislocation of the hip in newborns, the possible aetiological role of maternal hormones. Acta radiol. (Stockh.), 54, 123.

(1962). Pelvic instability in newborns. Acta radiol. (Stockh.), Suppl., 212, 1

- and PALMÉN, K (1963) Seasonal variation of birth dates of infants with congenital dislocation of the hip. Acta orthop. scand., 33, 127.

Bartha, O. (1968). Congenital Dislocation of the Hip and its Conservative Treatment. Akadémiai Kiadó, Budapest.

Chen, R., Weissman, S. L., Salama, R., and Klingberg, M. A. (1970). Congenital dislocation of the hip and seasonality: the gestational age of vulnerability to some seasonal factor. Amer. J. Epidem., 92, 287.

Coleman, S. S. (1968). Congenital dysplasia of the hip in the Navajo infant. Clin. Orthop., 56, 179.

Corrigan, C., and Segal, S. (1950). The incidence of congenital dislocation of the hip at Island Lake, Manitoba. Canad. med. Ass. J., 62, 535.

EDINBURGH CONGenital Malformations Register (1964-1967). cit. Wynne-Davies (1970b).

Fekete, M., Igazi, K., Járai, I., Lajos, L., Mestyán, GY., and WASZNER, Zs. (1968). Development of fetus in third trimenon. Gyermekgyógyászat, 19, 181 .
FINLAY, H. V. L., MAUdSLEY, R. H., and Busfield, P. I. (1967). Dislocatable hip and dislocated hip in the newborn infant. Brit. med. J., 4, 377.

GETZ, B. (1955). The hip in Lapps and its bearing on the $\overrightarrow{\vec{F}}$ problem of congenital dislocation. Acta. orthop. scand., Suppl., 18, 186.

Glauber, A., KonCZ, I., KullmanN, L., and Vizkelety, 흘 T. (1970). The role of orthopaedic examination in $\frac{\bar{s}}{\frac{1}{2}}$ newborn age and infancy in the prevention and $\mathbb{\otimes}$ treatment of congenital dislocation of the hip. Gyermekgyógyászat, $21,389$.

HERCZEGH, M. (1962). Screening for congenital disloca- $\vec{O}$ tion of the hip. Orv. Hetil., 103, 1128.

KraUs, B. S., and SchwarTzmanN, J. R. (1957). Con- $\vec{\omega}$ genital dislocation of the hip among the Fort Apaches Indians. J. Bone Jt Surg., 39A, 448.

LORENZ, A. (1920). Die sogenannte angeborene Hüftver- $\frac{\rho}{\partial}$ renkung. Enke. Stuttgart.

NAGURA, S. (1955). Zur Aetiologie der angeborenen Hüftverrenkung. Zbl. Chir., 80, 1933.

(1960). Zur Frage der Vererbung der angeborenen $O$ Hüftverrenkung. Zbl. Chir., 85, 2167.

Palmen, K. (1970). Preluxation of the hip joint. Acta ${ }_{7}^{-}$ orthop. scand., Suppl., 130, 8.

PAP, K. (1944). Congenital Dislocation of the Hip. Hajdu Kiadó, Debrecen.

(1954). Studies on congenital dislocation of the hip in Tiszántul. Népegészségügy, 35, 72.

RECORD, R. G., and EDWARDS, J. H. (1958). Enviroin- N mental influences related to the aetiology of congenitinl dislocation of the hip. Brit. J. prev. soc. Med., 12, 8.

vON ROSEN, S. (1970). Instability of the hip in the newborn. Acta orthop. scand., Suppl. 130, 13.

SALTER, R. B. (1968). Etiology, pathogenesis and possible prevention of congenital dislocation of the hip. Canad. med. Ass. J., 98, 933.

Weissman, S. L., and Salama, R. (1966). Treatment of congenital dislocation of the hip in the newborn infant. J. Bone Jt Surg., 48A, 1319.

WeSSEL, A. B. (1918). Laaghalte slegter i Finnmarken. T. norske Lageforen., 38, 337.

Wilkinson, J. A. (1963). Prime factors in the etiology of $\stackrel{5}{S}$ congenital dislocation of the hip. J. Bone Jt Surg., 45B, 268.

- (1966). Breech malposition and intrauterine dislocations. Proc. roy. Soc. Med., 59, 1106.

WyNNE-DAVIES, R. (1970a). Acetabular dysplasia ando familial joint laxity: two etiological factors in congenital dislocation of the hip. J. Bone Jt Surg., 52B $\frac{}{2}$ 704.

- (1970b). A family study of neonatal and late- $N$ diagnosis congenital dislocation of the hip. J. med. Genet., 7, 315.

WILSON, D. W. (1964). Congenital dislocation of the hip. J. Bone Jt Surg., 46B, 163. 